UDC 616-02: 614.78

DOI: $10.21668 /$ health.risk/2016.4.01.eng

\title{
SOCIAL AND HYGIENIC MONITORING TODAY: STATE AND PROSPECTS IN CONJUNCTION WITH THE RISK-BASED SUPERVISION
}

\author{
N.V. Zaitseva ${ }^{1,2}$, I.V. May ${ }^{1}$, D.A. Kiryanov ${ }^{1}$, D.V. Goryaev ${ }^{3}$, S.V. Kleyn ${ }^{4}$ \\ ${ }^{1}$ Federal Scientific Center for Medical and Preventive Health Risk Management Technologies, \\ 82 Monastyrskaya Str., Perm, 614045, Russian Federation \\ ${ }^{2}$ Perm State Medical University named after E.A. Wagner, 26 Petropavlovskaya Str., Perm, 614000, Russian Federation \\ ${ }^{3}$ Administration of the Federal Supervision Service for Consumer's Rights Protection and Human Welfare \\ in the Krasnoyarsk Region, 21 Karatanova Str., Krasnoyarsk, 660049, Russian Federation \\ ${ }^{4}$ Perm State National Research University, 15 Bukireva Str., Perm, 614990, Russian Federation
}

It is shown in the article that since the establishment in 1992 and until now the social and health monitoring (SHM) operates as a complex open system of extended collection and processing of heterogeneous data about the parameters of the environment, socio-economic indicators of living of the population of the country's regions, medical and demographic characteristics of society as a whole and of individual population groups. As part of the SHM system Rospotrebnadzor annually performs hundreds of thousands of instrumental measurements of objects in the environment of the Russian Federation. These federal and regional information assets have tremendous analytical capacity and allow a knowledge-based processing of information in the "health-environment" system for a variety of management tasks of sanitary and epidemiological situation.

Changing of the general paradigm of control and supervisory activities of Rospotrebnadzor and giving a fundamentally new status of control measures to researches and measurements of the system of social and hygienic monitoring without interaction with legal entities and individual entrepreneurs were important bases for further improvement of the SHM. The development of SHM in conjunction with the risk-based supervision model can significantly improve analytical capabilities, effectiveness and efficiency of each system. This development requires the adoption of a new edition of The statements of the SHM, the development of a scientific approach to the formation of "risk profiles" of objects of sanitary and epidemiological surveillance; the development of methodological approaches to the selection of points and formation of programs of instrumental studies of air, water and soil as the control activities in the areas of influence of economic entities. Of great current interest are the development and consolidation of regulatory requirements for the registration of the results of sampling and measurement in the course of monitoring activities in the framework of the SHM; the establishment of criteria for associating violations of hygienic standards of air quality, natural and drinking water and soil with the facts of causing threat to life and health of citizens; the development of scientific and organizational approaches

(C) Zaitseva N.V., May I.V., Kiryanov D.A., Goryaev D.V., Kleyn S.V., 2016

Nina V. Zaitseva - Member of RAS, Doctor of Medical Sciences, Professor, Director (e-mail: znv@fcrisk.ru; tel.: +7 (342) 233-11-25).

Irina V. May - Doctor of Biological Sciences, Professor, Deputy Director for Research (e-mail: may@fcrisk.ru; tel.: +7 (342) 237-25-47).

Dmitry A. Kiryanov - PhD in Engineering, head of the department of mathematical modeling of systems and processes (e-mail: kda@fcrisk.ru; tel.: +7 (342) 237-18-04)

Dmitriy V. Goryaev - director, chief state sanitary doctor of the Krasnoyarsk Region (e-mail: goryaev_dv@ 24.rospotrebnadzor.ru; tel.: +7 (391) 226-89-50).

Svetlana V. Kleyn - Candidate of Medical Science, Associate Professor of Human Ecology and Life Safety (e-mail: kleyn@fcrisk.ru; tel.: +7 (342) 237-18-04). 
to the establishment, registration and proof of cases of harm to human health in violation of the mandatory requirements of the objects of sanitary and epidemiological surveillance.

Key words: socio-hygienic monitoring, control and surveillance activities, sanitary-epidemiological wellbeing.

Socio-hygienic monitoring as a state system for surveillance over public health and environment, analysis, assessment and prognosis, as well as evaluation of cause-effect relationship between the population health and environmental factors impact, is implemented by the bodies and organizations of Rospotrebnadzor (Federal Service for Surveillance over Consumer rights protection and human wellbeing) for over 20 years.

Established in $1994^{1}$ and being developed consistently with the federal ${ }^{2,3}$ documents and Rospotrebnadzor ${ }^{4,5,6,7}$ regulations, the social and hygienic monitoring was aimed at accumulating data to evaluate the causeeffect relationship between the Russians health and the impact factors thereto, and performing deep high-tech analytical tasks for the benefit of the decision-makers at various federal levels.

Starting from its foundation and up to date, SHM functions as a complex open system for an ongoing collection and processing various data on the environment parameters, socio-economic indices of the country's regions, medical and demographic characteristics of the society as a whole and of individual population segments ${ }^{8}$.

No any other state monitoring system in the Russian Federation is such interdepartmental by its type and focused on the collec- tion and processing of such diverse information. As part of SHM system activities, Rospotrebnadzor has been carrying out instrumental measurements in all the subjects of the Russian Federation since 1994. Over 2015 only, the ambient air measurements were taken at 2290 monitoring points and observation posts (over 1,350 thousand air samples were studied); measurements of centralized drinking water supply systems indicators: at 11,145 monitoring points; soil measurements: at 8,165 monitoring points [17]. The number of monitoring points and scope of measurements in the previous years were even larger. The extensive and dynamic information

reflects the habitat state of almost the entire population of the country.

The task of structuring, accumulation and annual cross-spectrum analysis of the data in a single system of the federal information fund required efforts of all structural divisions within Rospotrebnadzor in the regions, departmental research institutions, central office, Federal Center for Hygiene and Epidemiology. Major efforts have been made to establishing and keeping the inter-agency arrangements and the procedure of interaction $[1,7,9]$.

Information being collected in SHM, of course, has a number of shortcomings that should be addressed and revised. The system requires strict initial control of the data re-

\footnotetext{
${ }^{1}$ RF Government Decree of 06.10.1994, No. 1146 "On Approval of socio -hygienic monitoring".

${ }^{2}$ RF Government Decree of No. 426 of June, 1, 2000. "On Approval of provisions on socio -hygienic monitoring".

${ }^{3}$ RF Government Decree of 02.02.2006 No. 60 " On Approval of provisions on implementation of socio -hygienic monitoring".

${ }^{4}$ Order of the Federal Service for Surveillance over Consumer Rights Protection and Human Wellbeing of 30.12.2005, No. 810

"On the list of indices and data for establishment of the Federal Information Fund of socio -hygienic monitoring"

${ }^{5}$ Order of the Federal Service for Surveillance over Consumer Rights Protection and Human Wellbeing of 07.02.2007 No. 33

"On Amendments to the procedure for socio-hygienic monitoring, data reporting and sharing"

${ }^{6}$ Order of the Federal Service for Surveillance over Consumer Rights Protection and Human Wellbeing of January, $31^{\text {st }}, 2008$, No. 35 "On criteria for determining the baseline minimum level for arranging and execution of socio-hygienic monitoring" ${ }^{7}$ Order of the Federal Service for Surveillance over Consumer Rights Protection and Human Wellbeing of M arch, $3^{\text {rd }}, 2008$, No. 69 "On action-plan to further improvement of social and hygienic monitoring"

${ }^{8}$ Order of socio-hygienic monitoring execution, data reporting and sharing between federal executive bodies, institutions and other organizations involved in socio-hygienic monitoring. Approved by the Ch. Public Health State Officer Order. ddt. 17.11.2006 No. 37.
} 
ceived from the regions $[16,19]$. At the same time, federal and regional information funds data accumulated for over more than 20 years are in many respects unified in structure and collection procedure, have enormous analytical capacity and allow for knowledge-based processing of the information within "healthenvironment" system for a variety of tasks in controlling the sanitary and epidemiological situation. And there are numerous examples thereto. Everywhere SHM data are used for the integrated hygienic assessment of the regions $[1,4,6,11,19]$. Publications by the experts from Sverdlovsk, Kaliningrad, Voronezh and Lipetsk regions, the Republic of Tatarstan, a number of other regions show that the information on negative effects of environment quality towards population health are the basis for the regional action-plans in the field of sanitary and epidemiological welfare of the population [22,26,28,29]. In St. Petersburg, Moscow, Irkutsk regions, SHM results were used in urban development and spatial planning $[3,10,13]$. The results of implementing the socio-hygienic monitoring data for the management tasks in a number of lifestyle factors have been published [9]. The regions gain experience in cross-spectrum analysis of the official statistical reporting forms data and primary materials on the population health indices [19].

According to the results of sociohygienic monitoring, about 3,500 management decisions are taken throughout the country every year [17]. These are the decisions realized as the actions within the framework of the regional dedicated programs for the prevention of mass non-infectious diseases due to environmental factors and individual hygiene and sanitation, health-care and other activities.

It should be noted that the system initial- ly allowed for functional development. The strongest progressive movement in SHM since its launch has been the use of health risk assessment methodology at exposure to environmental hazards. The latter was supported by the approved Regulation "On the use of risk assessment methodology for managing environmental quality and population health in the Russian Federation"9. This document, strategic in nature, led to a series of effective practical steps to substantially enhance the analytical capabilities of monitoring. The risk assessment methodology allowed new approaches to evaluating the links in "environment-health" system and identifying the

causes and conditions of health disorders. Now we can structure the risks, assess the contribution of individual factors in the overall risk and prioritize them; define the localities (zones, areas) of the highest level risks to health, and on the contrary, the most favored localities; forecast negative or positive shifts in the population health by analyzing trends in habitat quality $[1,12,18]$. There have appeared works developing and completing the traditional approaches to assessment of chemical risks and allowing for assessment of the health risks at exposure to chemical, as well as to a number of physical factors: noise, electromagnetic radiation, lifestyle factors, etc., using a single methodological approach thereto. [14].

Risk assessment in many ways did even "replace" the targeted epidemiological studies in the regions. Based on the assessment of health risks within SHM, decisions are taken to decrease pollution, optimal diets are developed, rehabilitation and preventive care measures for unacceptable risk areas are implemented, proposals for optimizing supervisory activities are introduced $[8,12,20,21$, $25,30,31]$. Risk assessment is seen as an es-

\footnotetext{
${ }^{9}$ Regulation "On the use of risk assessment methodology for managing environmental quality and population health in the Russian Federation" Approved by the Ch. Public Health State Officer of Russia No. 25 of 10.11.1997; Ch. State Inspector on Environment Protection of Russia No. 03-19/24-3483 of 10.11.1997

${ }^{10}$ Federal Law No. 294-FZ "On protection of the legal entities and individual entrepreneurs rights in the exercise of state control (surveillance) and municipal control" as amended on 07.03.2016, (Article 8.1. Use of risk-based approach in the organization of state control (surveillance) (introduced with the FederalLlaw of 13.07.2015 No. 246-FZ)

${ }^{11}$ Federal Law of June, $29^{\text {th }}, 2016$, No. 277- FZ "On amendments to the Federal Law "On protection of the legal entities and individual entrepreneurs rights in the exercise of state control (surveillance) and municipal control" and Federal Law "On strategic planning in the Russian Federation".
} 
sential component in forming the basis for evidence of harm to human health [9].

Introducing new approaches in SHM practice has greatly affected also the demand for the outcomes of the system. Based on materials of Ivanenko et al. [23], SHM system improvement and annual reports of the observations on the state of environment and health of the people living in the capital implied positive medical and demographic trends, clear stabilization or decline in morbidity, authentically associated with environmental risk factors, reduced incidence of life-threatening diseases (perinatal pathology and congenital malformations, reduced the incidence of foodborne diseases related to social factors). Thus, according to Kuzmin S.V. et al. [27], using the risk assessment and management methodology in Sverdlovsk region led to an over threetimes increase in the number of management decisions taken by the executive authorities and aimed at ensuring sanitary and epidemiological welfare of the population. The number of consumer rights violations resolved through the pre-trial process increased in 1.3 times, the proportion of Rospotrebnadzor claims satisfied on behalf of the groups of persons increased by 1.2 times.

It's no doubt the system of social and hygienic monitoring has wide prospects for further development. Geo-information technologies are in progress, which, based on vector maps of localities and using high-end software, allow for integration of the diverse, geographically-dispersed data and generation of the fundamentally new information visualized also in a well-understood forms of evidence $[12,13,24]$. The biological monitoring methods, which have every reason to be included in the overall SHM structure, are being developed $[5,15,32,33]$.

However, the major grounds for "reformatting" SHM is shifting the overall paradigm of Rospotrebnadzor control and supervisory activities towards risk-based model ${ }^{10}$ and giving the research and measurements within socio-hygienic monitoring system an entirely new status of control activities without legal entities and individual entrepreneurs ${ }^{11}$ involved.

Obviously, search and legislative consolidation of the new forms and instruments of control in the country is realized as part of the surveillance activities reform on the whole, the purpose thereof is to reduce total administrative burden on business. This assumes a strong focus of the supervisory authorities in the high-risk areas and excluding the objects of low-risk to the values under state protection from the routine monitoring. At the same time, the first steps towards implementation of the risk-based model have already been made: categorization of sanitary and epidemiological surveillance objects by risk of harm to health, when planning the activities for 2017, showed that about $36 \%$ objects can be categorized as low-risk objects and excluded from the routine surveillance.

However, the state control liberalization should not result in a loss of controllability of the sanitary-epidemiological situation by Rospotrebnadzor bodies. And one of the means to prevent such losses is a beneficial convergence of the control and surveillance activities system and socio-hygienic monitoring.

Pairing the two functions and systems of Rospotrebnadzor is fairly harmonious and reasonable. Since SHM initially was targeted mostly on establishing the measures to eliminate harmful environmental effect on the population, it's obvious that these measurements and research should be focused mostly on the harmful factors affected areas. In this case, the vital task of the current phase is a scientific and methodological rationale for the selection of monitoring points and creating the programs using the research tools for studying

\footnotetext{
${ }^{12}$ RF Government Decree of 17.08.2016, No. 806 "On use of risk-oriented approach to organization of certain types of state control (surveillance) and amendments to certain acts of the Russian Federation Government" (together with the "Terms of reference for legal entities and individual entrepreneurs activities and (or) for the production facilities they use to a certain risk category or a particular class (category) of hazard"
} 
ambient air, natural, drinking waters and soils in the affected areas of the objects of extremely high, high and significant risk to health.

The choice of points and research programs must provide for reliable evidence and results, including the indicators of:

- threat of harm to human life and health;

- objects forming threat of harm to life and health (if such threat exists).

The above statement of the task requires the social and hygienic monitoring both to realize its original function on forming the evidence of causal relationships in the "healthenvironment" system, as well as to implement new function on establishing the source of threat. Taking into account that sources of threats are primarily the objects of sanitaryepidemiological control, the convergence of SHM and its control and surveillance activities is getting urgent obviously.

The principal diagram of convergence for the system of socio-hygienic monitoring and the risk-oriented control and surveillance is shown in Figure 1.

Pairing SHM and control \& surveillance activities is implemented by the consistent steps:

- introducing the register of legal entities and individual entrepreneurs subject to surveillance;

- assessment, per each object under surveillance, of the potential risks of harm to health for the tasks of categorization (classification) and planning the surveillance activities $^{12}$;

- selection of the objects to be classified as of very high and high risk to public health in the region; to localities;

- geographical reference of these objects

- rationale for the "risk profiles" of the objects under surveillance, i.e. a system of indices characterizing the priority factors contributing to overall risk level of an object, and their inter-relationships;

- convergence of the object level of risk to health and the regional demographic indices, selecting localities of the highest mortality and morbidity share associated with the risk generated by the objects under surveillance due to violations of sanitary legislation.

- establishing SHM programs considering the following requirements: monitoring point is located in the area of the highest potential risk of harm to health by the object under surveillance in violation of sanitary legislation and the highest mortality and morbidity associated with the negative factor; monitoring program aims to measure the factors that generate the highest risks to health; monitoring program includes a sufficient minimum number of observations for the next analytical processing.

Outcome analysis of the control and surveillance activities is carried out in convergence with SHM results. If SHM results showed the levels of environment pollution hazardous to human health, the crucial task then is to revise the control \& surveillance activities in relation to the objects that can be a source of this pollution.

The given approach best corresponds to the control and surveillance activities focus on the end-result: preservation of public health. However, the new challenges significantly upgrade the requirements for each element of the socio-hygienic monitoring and risk-oriented model of the control \& surveillance service.

Requirements for the registers quality of the objects under sanitary and epidemiological surveillance, for correctness and transparency in evaluating the category of the object by the risk of harm to health are upgraded.

It appears a task of creating the risk "profiles" and selecting the specific riskinduced factors of chemical, biological, physical nature, which should be measured.

It's increasing the demand for situational modeling tools, including GIS-based platforms.

It is becoming urgent the development of scientific and methodological basis of records, evidence, registration of cases of harm to human life and health due to violations of sanitary legislation, confirmed by SHM measurements. At the same time, Rospotrebnadzor bodies and organizations in many respects are ready to innovative changes. 
CONTROL \& SURVEILLANCE ACTIVITIES

\section{Introducing the register of the objects under surveillance}

- assessment of health risk to assign a category (class) to an object - formation of the objects risk profiles

- geographical distribution of potential harm risks

\section{SOCIO-HYGIENIC \\ MONITORING}

\section{Collecting and processing data on en- vironment and human health}

- Assessment of levels and geographical distribution of the environment quality parameters

- Assessment of levels and geographical distribution of the population health indices

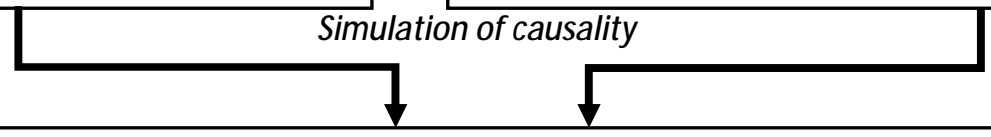

System of interlinks between health indices and risk of harm to health by the objects under surveillance due to breach of legislation

Risk profiles based on the types of laws violations, on the data of emissions, effluents
Implementation of control \& surveillance measures мероприяти

Measures of administrative enforcement

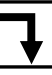

Identification of priorities: localities of SHM deployment, objects under surveillance within locality, parameters to be included in the monitoring programs as activities of control

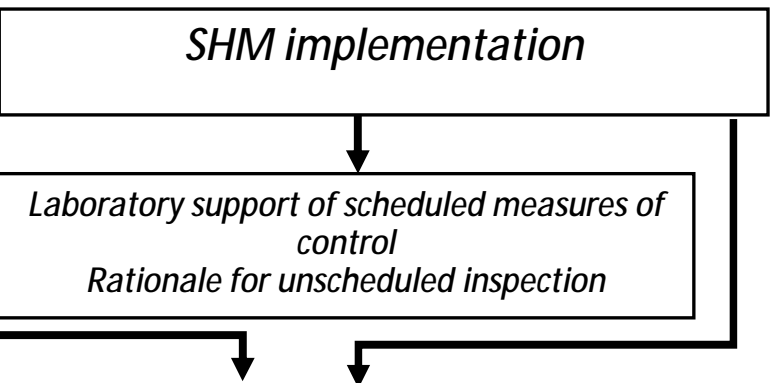

Cross-spectrum analysis of SHM observation results and control \& surveillance measures. Analysis of the indices dynamics for environmental objects quality in the affected areas of

the different categories objects under surveillance by the levels of harm to health.

Trend analysis of the population health indices.

Assessment of efficiency and performance of the control \& surveillance measures based on the socio-hygienic monitoring data.

Developing laboratory support pro-
grams for control \& surveillance
measures for the next year.
Rationale for inspections plans for the
planning periodна плановый период

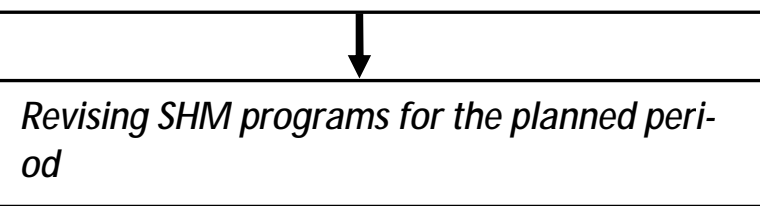

Fig.1. Conceptual diagram of data integration in environment and health monitoring and control \& surveillance activities 
In the example of the Krasnoyarsk region, in order to develop and improve the system of SHM together with the risk-oriented surveillance, the first few steps are taken:

- the register of objects under surveillance is made (about 57 thousand objects, affecting the quality of air, water, soil, climate, etc.);

- the classification of objects under surveillance is made upon the assessment results of the risk of harm due to violations of sanitary legislation in the established procedure;

- all the objects under surveillance in ARCGIS (version 9.0) are linked to the vector map of the region and the municipality area at the place of actual location;

- the total potential risks of harm to health, being generated as a result of violations in the sanitary legislation mandatory requirements by the objects under surveillance in the Krasnoyarsk region, have been evaluated per each municipality (please, see the example, Fig. 2);

- the scope of instrumental and other studies under SHM have been analyzed per each area (please, see the example, Fig. 3).

It's found that the demographic and health parameters data are sufficient for further in-depth analysis of the cause-and-effect relationships in the "health-environment" system, while the environmental factors data are not always adequate to the potential risks.

If high risks in the localities of Norilsk, Divnogorosk, Sosnovoborsk are secured with the adequately intensive monitoring system, the high risk of harm to health in the cities of Kansk, Sharypovo, Nazarovo, Achinsk, of Birilyussy area, etc. require complex observation over the risk factors. A high level of SHM intensity in Minusinsk does not correspond to the relevant threats and hazards level that indicates the possibility to redistribute instrumental studies within SHM. Thus, the first reconnoitring steps already allow identify the main areas of SHM system optimization at the regional level.

In future, SHM optimization assumes:

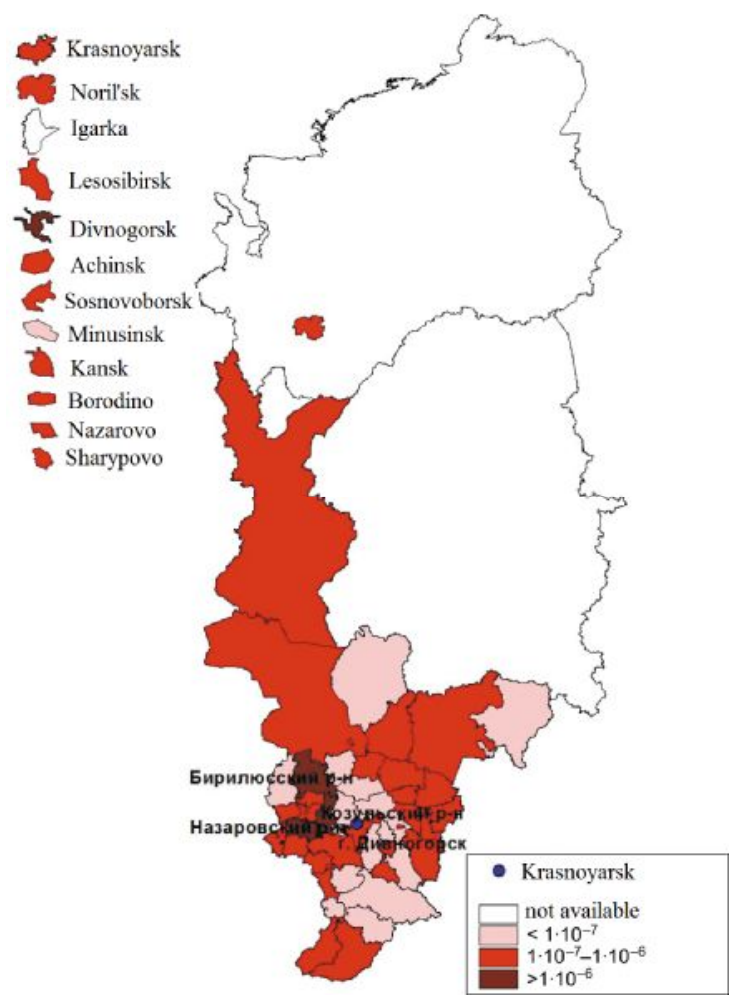

Fig. 2 Total potential risk of harm to public health due to violations in the sanitary legislation mandatory requirements by the objects under surveillance in the Krasnoyarsk region

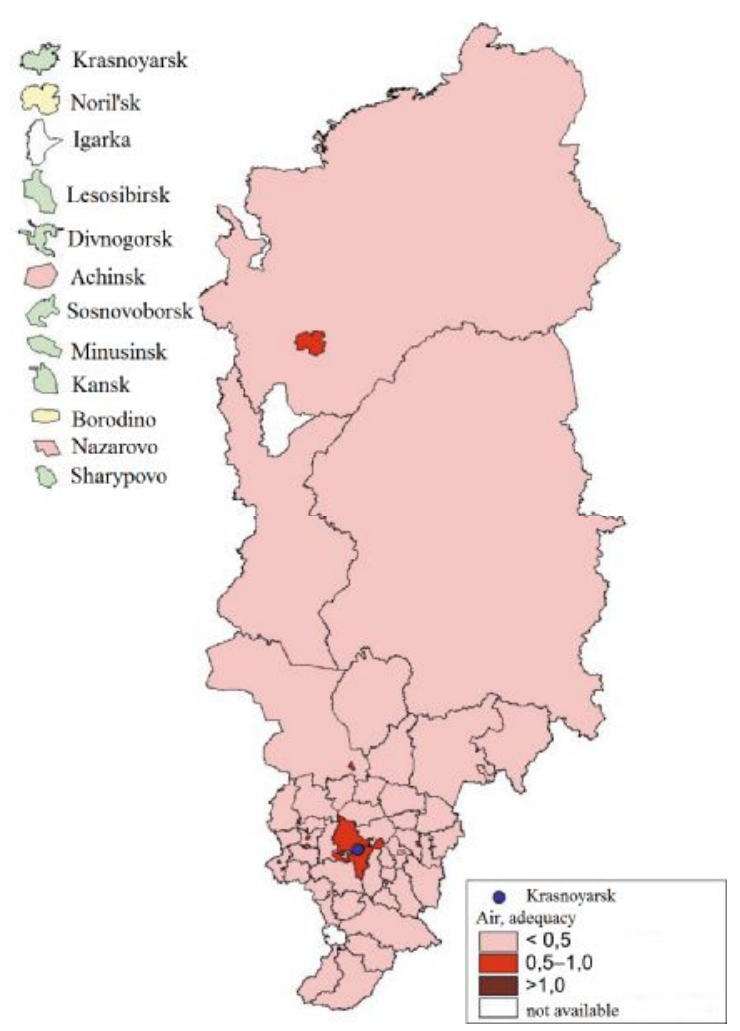

Fig. 3 Ratio of the indices measured to the number of influencing factors 
- an estimation of mortality and morbidity share in the population of the region's municipalities formed by the potential environmental risks;

- a selection, per each priority area, of the affected zones by the objects of extremely high and high risk of harm to public health;

- an analysis of the priority riskgenerating factors (in this case, a set of risk factors can be quite individual for each area)

Upon the outcomes of SHM and control and surveillance activities, it is expected not only to reveal (confirm) causal relationships in the system "risk factors - environment quality public health", but also to perform a crossspectrum analysis of "Rospotrebnadzor actions - environment quality - public health". The latter will allow eventually to assess the performance and efficiency of the control and surveillance activities, as well as to develop a series of recommendations for the third-party stakeholders in the control process over the environment and population health, i.e. the municipal authorities, enterprises, organizations, and civil society.

Thus, the development of social and hygienic monitoring system together with the risk-oriented model of control and surveillance activities can enhance significantly the analytical capabilities and efficiency of each system. However, such a development requires as soon as possible to:

- approve the new edition of the Regulation on SHM in view of the Federal Law dated June, 29 ${ }^{\text {th }}, 2016$ No. 277- FZ "On Amend- ments to the Federal Law "On protection of rights of legal entities and individual entrepreneurs in the exercise of state control (surveillance) and municipal control" and the Federal law "On the strategic planning in the Russian Federation".

- develop a scientific approach to the "risk profiles" for the objects under sanitaryepidemiological surveillance due to violations of sanitary legislation;

- develop and document methodical approaches to choosing the monitoring points and creating the instrumental programs for studying ambient air, natural, drinking waters and soils in the affected areas of the objects of extremely high, high and significant risk to health, as the measures of control, without legal entities and individual entrepreneurs involved;

- develop and formalize regulatory requirements for sampling and measurements results registration in the course of monitoring activities without legal entities and individual entrepreneurs involved;

- establish criteria for classifying the violations of hygienic standards for the air, natural and drinking water, and soil quality in respect to the facts of causing threat to life and health of the citizens;

- develop scientific and institutional approaches to establishment, evidence and registration of cases of harm to human health at violations in the sanitary legislation mandatory requirements by the objects under sanitary and epidemiological surveillance.

\section{References}

1. Avaliani S.L., Revich B.A., Zaharov V.M. Monitoring zdorov'ja cheloveka i zdorov'ja sredy (Regional'naja jekologicheskaja politika) [Monitoring of human and environmental health (Regional Environmental Policy)]. Moscow: Centr jekologicheskoj politiki Rossii, 2001, 76 p. (in Russian).

2. Zaitseva N.V., Alekseev V.B., Lebedeva-Nesevrya N.A., Barg A.O., Gasnikov V.K. Analiz vlijanija social'no-demograficheskih faktorov na rasprostranennost' nekotoryh form deviantnogo povedenija [Analysis of the social-demographic factors impact on the popularity of deviant behaviour]. Social'nye aspekty zdorov'ja naselenija, 2011, vol. 19, no. 3, pp. 24 (in Russian).

3. Bobkova T.E. Zonirovanie territorii perspektivnoj zastrojki s primeneniem metodologii ocenki riska zdorov'ju naselenija [Future built-up area zoning by applying the methodology for assessing the population health risk]. Gigiena $i$ sanitarija, 2009, no. 6, pp. 38-41 (in Russian).

4. Boev V.M. Metodologija kompleksnoj ocenki antropogennyh i social'no-jekonomicheskih faktorov v formirovanii riska dlja zdorov'ja naselenija [Methodology for integrated assessment of an- 
thropogenic and socioeconomic factors in the formation of a human health risk]. Gigiena $i$ sanitarija, 2009, no. 4, pp. 4-9 (in Russian).

5. Vanyaeva E.P., Malyh O.L., Jarushin S.V. Biomonitoring kak vazhnejshij jetap gigienicheskoj diagnostiki $\mathrm{v}$ sisteme mediko-profilakticheskih tehnologij dlja zdorov'ja naselenija, podverzhennogo risku v svjazi s himicheskim zagrjazneniem sredy obitanija [Biomonitoring as the most important step in the hygienic diagnostics in the system of healthcare technologies for health of the population at risk due to chemical pollution of the environment]. Aktual'nye problemy bezopasnosti i ocenki riska zdorov'ju naselenija pri vozdejstvii faktorov sredy obitanija: materialy Vserossijskoj nauchno-prakticheskoj konferencii s mezhdunarodnym uchastiem [Current safety and health risk assessment problems of the population under the impact of environmental factors. Proceedings of the all-Russian scientific-practical conference with international participation]. In: professor A.Ju. Popova, akademik RAN N.V. Zajceva, eds. Perm, 2014, pp. 571-573 (in Russian).

6. Grigor'ev Ju.I., Ljapina N.V. Ocenka riska zagrjaznenija pit'evoj vody dlja zdorov'ja detej Tul'skoj oblasti [Assessment of risk of contamination of drinking]. Gigiena i sanitarija, 2013, no. 3, pp. 36-38 (in Russian).

7. Zhavoronok L.G. Social'no-gigienicheskij monitoring - instrument upravlenija kachestvom sredy obitanija i zdorov'ja naselenija [Socio-hygienic monitoring as the tool of environment quality and public health management]. Uchenye zapiski Rossijskogo gosudarstvennogo social'nogo universiteta, 2009, no. 5, pp. 124-129 (in Russian).

8. Zadiran A.V., Sinicyna O.O., Meshkov N.A. Risk vozniknovenija kozhnyh zabolevanij gribkovoj jetiologii pri poseshhenii plavatel'nyh bassejnov [Visit a swimming pool in moscow as a risk of skin diseases of fungal etiology]. Gigiena i sanitarija, 2012, no. 4, pp. 19-22 (in Russian).

9. Zaitseva N.V., Kleyn S.V. Ocenka riska zdorov'ju naselenija pri vozdejstvii vodnogo peroral'nogo faktora sredy obitanija v uslovijah krupnogo promyshlennogo centra dlja zadach social'no-gigienicheskogo monitoringa (na primere goroda Permi) [Estimation of risk to health of the population at impact of water peroral factor of inhabitancy in conditions of large industrial centre for problems of socially-hygienic monitoring (on example of Perm) ]. Izvestija samarskogo nauchnogo centra Rossijskoj Akademii Nauk, 2009, vol. 11, no. 1-6, pp. 1139-1143 (in Russian).

10. Zaprudnova O.G. Sistema social'no-gigienicheskogo monitoringa v praktike gradostroitel'stva v Sergievo-Posadskom rajone Moskovskoj oblasti [System of social-hygienic monitoring in practice of town construction in sergiev posad district of Moscow region]. Jekologija cheloveka, 2006, no. 10, pp. $42-45$ (in Russian).

11. Kireeva I.S., Chernichenko I.A., Litvichenko O.N. Gigienicheskaja ocenka riska zagrjaznenija atmosfernogo vozduha promyshlennyh gorodov Ukrainy dlja zdorov'ja naselenija [Hygienic assessment of the risk of ambient air pollution to human health in the Ukraine's industrial towns]. Gigiena i sanitarija, 2007, no. 1, pp. 17-21 (in Russian).

12. Kiselev A.V., Kucenko G.I., Shherbo A.P. Nauchnoe obosnovanie sistemy ocenki riska zdorov'ju $\mathrm{v}$ gigienicheskom monitoringe promyshlennogo goroda [Scientific substantiation of health risk assessment system in hygiene monitoring of industrial city]. Hrizostom, 2001, 208 p. (in Russian).

13. Lim T.E. Nekotorye aspekty organizacii sistemy social'no-gigienicheskogo monitoringa pri stroitel'stve i jekspluatacii obezdnyh avtomobil'nyh dorog [Some aspects of the organisation of system of socially-hygienic monitoring in building and operation of roundabout highways on an example of St.Petersburg]. Sibirskij medicinskij zhurnal (Irkutsk), 2009, vol. 88, no 5, pp. 89-91 (in Russian).

14. Zaitseva N.V., Trusov P.V., Shur P.Z., Kiryanov D.A., Chigvincev V.M., Tsinker M.Ju. Metodicheskie podhody $\mathrm{k}$ ocenke riska vozdejstvija raznorodnyh faktorov sredy obitanija na zdorov'e naselenija na osnove jevoljucionnyh modelej [Methodical approaches to health risk assessment of heterogeneous environmental factors based on evolutionary models]. Analiz riska zdorov'ju, 2013, no. 1, pp. 15-23. DOI: 10.21668/health.risk/2013.1.02 (in Russian).

15. Gileva O.V., Ulanova T.S., Vejhman G.A., Nedoshitova A.V., Stenno E.V. Metodicheskoe obespechenie opredelenija toksichnyh i jessencial'nyh jelementov v biologicheskih sredah cheloveka dlja zadach social'no-gigienicheskogo monitoringa i biomedicinskih issledovanij [Methodical assurance of the assessment of toxic and essential elements in human biological matrices]. Gigiena $i$ sanitarija, 2016, vol. 95, no. 1, pp. 116-121 (in Russian). 
16. Nechuhaeva E.M., Maslov D.V., Afanas'eva S.I. Aktual'nye zadachi social'no-gigienicheskogo monitoringa na regional'nom urovne [Current problems of social and hygienic monitoring at the regional level]. Zdorov'e. Medicinskaja jekologija. Nauka, 2010, vol. 41-42, no. 1-2, pp. 39-40 (in Russian).

17. O sostojanii sanitarno-jepidemiologicheskogo blagopoluchija naselenija v Rossijskoj Federacii v 2015 godu: Gosudarstvennyj doklad [On the state sanitary and epidemiological welfare of the population in the Russian Federation in 2015: State Report]. Moscow: Federal'naja sluzhba po nadzoru v sfere zashhity prav potrebitelej i blagopoluchija cheloveka, 2016, 200 p. (in Russian).

18. Onishchenko G.G. Koncepcija riska i ee mesto v sisteme social'no-gigienicheskogo monitoringa (problemy i puti reshenija) [Conception of health risks and its place in the system of sociohygienic monitoring (problems and approaches to their solution)]. Vestnik Rossijskoj akademii medicinskih nauk, 2005, no. 11, pp. 27-33 (in Russian).

19. Buzinov R.V., Ungurjanu T.N., Lazareva N.K., Gudkov A.B. Organizacija social'no gigienicheskogo monitoringa na territorii Arhangel'skoj oblasti [Organization of social-hygienic monitorinin Arkhangelsk region]. Jekologija cheloveka, 2006, no. 7, pp. 3-8 (in Russian).

20. Kuz'min S.V., Privalova L.I., Kacnel'son B.A., Nikonov B.I., Gurvich V.B., Voronin S.A., Malyh O.L., Kornilkov A.S., Chebotarkova S.A., Kochneva N.I. Ocenka riska i jekologojepidemiologicheskie issledovanija kak vzaimosvjazannye instrumenty social'no-gigienicheskogo monitoringa na mestnom i regional'nom urovnjah [Risk assessment and environmental and epidemiological studies as interrelated tools of sociohygienic monitoring at the local and regional levels]. Gigiena $i$ sanitarija, 2004, no. 5, pp. 62 (in Russian).

21. Boev V.M., Setko A.G., Boev M.V., Frolov A.B. Ocenka summarnogo riska zdorov'ju naselenija himicheskih faktorov gorodskoj sredy [Estimation of total public health risks caused by chemical factors of the urban environment]. Sovremennye problemy gigieny goroda, metodologija i puti reshenija: materialy plenuma nauchnogo soveta po jekologii cheloveka i gigiene okruzhajushhej sredy RAMN i Minzdravsocrazvitija Rossijskoj Federacii [Modern problems of city hygiene, methodology and solutions: Materials of Plenum of Scientific Council for Human Ecology and Environmental Health of Medical Sciences and Health and Social Development of the Russian Federation]. Moscow, 2006, pp. 41-43 (in Russian).

22. Pichuzhkina N.M. Opyt ispol'zovanija metodologii ocenki riska dlja zdorov'ja naselenija pri vedenii social'no-gigienicheskogo monitoringa $\mathrm{v}$ Voronezhskoj oblasti [Experience of use of methodology of estimation of risks for population's health under conducting of social-hygienic monitoring in Voronezh region]. Zdorov'e naselenija i sreda obitanija, 2006, no. 10, pp. $49-55$ (in Russian)

23. Ivanenko A.V., Volkova I.F., Kornienko A.P., Sudakova E.V. Pokazateli sostojanija zdorov'ja naselenija Moskvy, harakterizujushhie jeffektivnost' social'no-gigienicheskogo monitoringa [Health indices, which characterize the efficiency of the sociohygienic monitoring system, in-the Moscow population]. Gigiena i sanitarija, 2006, no. 5, pp. 92-94 (in Russian).

24. Borshchuk E.L., Boev V.M., Sermjagina E.G., Dunaev V.N., Vereshhagin N.N. Primenenie GIS-tehnologij pri vedenii social'no-gigienicheskogo monitoringa v g. Orenburge [Application of GIS technologies in the management of social and hygienic monitoring in Orenburg]. Social'no-gigienicheskij monitoring sredy obitanija i zdorov'ja naselenija: sbornik trudov nauchno-prakticheskoj konferencii [Socio-hygienic monitoring of the environment and human health: Proceedings of the scientific-practical conference]. Orenburg, Print-Servis, 2004, pp. 35-36 (in Russian).

25. Gurvich V.B., Kuz'min S.V., Nikonov B.I., Plotko Je.G., Jarushin S.V., Malyh O.L., Soloboeva Ju.I., Kuz'mina E.A., Plotnikova I.A., Vanjaeva E.P. Sistema profilakticheskih meroprijatij po upravleniju riskom dlja zdorov'ja naselenija, podvergajushhegosja vlijaniju himicheski zagrjaznennoj sredy obitanija (na primere Sverdlovskoj oblasti) [The system of preventive actions aimed at managing population health risks from chemical contamination of environmental media (the experience of the Sverdlovsk region)]. Zdorov'e naselenija i sreda obitanija, 2013, vol. 246, no. 9, pp. 6-10 (in Russian).

26. Kuz'min S.V., Gurvich V.B., Dikonskaja O.V., Malyh O.L. Jarushin S.V., Romanov S.V., Kornilkov A.S. Social'no-gigienicheskij monitoring - integrirovannaja sistema ocenki i upravlenija riskom dlja zdorov'ja naselenija na regional'nom urovne [The socio-hygienic monitoring as an integral system for health risk assessment and risk management at the regional level]. Gigiena i sanitarija, 2013, no. 1, pp. 3032 (in Russian). 
27. Gurvich V.B., Kuz'min S.V., Malyh O.L., Jarushin S.V. Social'no-gigienicheskij monitoring integrirovannaja sistema ocenki i upravlenija riskom dlja zdorov'ja naselenija na regional'nom urovne [Public health monitoring - integrated assessment and management of risk for health at the regional level]. Sanitarnyj vrach, 2014, no. 1, pp. 29-31 (in Russian).

28. Surzhikov D.V., Oleshhenko A.M., Bol'shakov V.V. Ocenka riska dlja zdorov'ja naselenija Krasnojarska v sisteme social'no-gigienicheskogo monitoringa [Health Risk Assessment of the population of Krasnoyarsk in the socio-hygienic monitoring system]. Vestnik mezhregional'noj associacii "Zdravoohranenie Sibiri", 2004, no. 1, pp. 33-34 (in Russian).

29. Sukharev A.G., Ignatova L.F. Social'no-gigienicheskij monitoring detej kak metodologija celevyh profilakticheskih programm [Socio-hygienic monitoring of children as a methodology of target prevention programs]. Voprosy sovremennoj pediatrii, 2006, vol. 5, no. 1, pp. 557 (in Russian)

30. Trukhina G.M. Ocenka mikrobiologicheskogo riska sredy obitanija dlja zdorov'ja naselenija v sisteme social'no-gigienicheskogo monitoringa [Assessment of an environmental microbiological risk to the population's health in the sociohygienic monitoring system]. Zdravoohranenie Rossijskoj Federacii, 2008, no. 1, pp. 43 (in Russian).

31. Tsunina N.M., Ajupova L.V. Ocenka riska zdorov'ju naselenija ot zagrjaznenija produktov pitanija kontaminantami (g.o.* Samara, g.o. Tol'jatti) [Population health risk assessment from contamination of food products with contaminants (c.d. Samara, c.d. Togliatti)]. Analiz riska zdorov'ju, 2014, no. 1, pp. 57-64. DOI: 10.21668/health.risk/2014.1.07 (in Russian).

32. Daland R. Juberg, J. Bus, Diane S. Katz. The Opportunities and Limitations of Biomonitoring. Policy brief. February 2008. Available at: https: //www.mackinac.org/S2008-01 (18.11.2016).

33. Sexton K., Needham L.L., Pirkle J.L. Mesuaring chemicals in human tissues is the «gold standard» for assessing peoples exposure to pollution. American Scientist, 2004, vol. 92, no. 1, pp. 38-45.

Zaitseva N.V., May I.V., Kiryanov D.A., Goryaev D.V., Kleyn S.V. Social and hygienic monitoring today: state and prospects in conjunction with the risk-based supervision. Health Risk Analysis, 2016, no. 4, pp. 4-14. DOI: 10.21668/health.risk/2016.4.01.eng

Received: 23.08.2016

Accepted: 04.12.2016

Published: 30.12.2016 